Journal of Social Sciences (COES\&RJ-JSS)

ISSN (E): 2305-9249 ISSN (P): 2305-9494

Publisher: Centre of Excellence for Scientific \& Research Journalism, COES\&RJ LLC

Online Publication Date: $1^{\text {st }}$ April 2017

Online Issue: Volume 6, Number 2 Special, April 2017

http://centreofexcellence.net/J/JSS/JSS\%20Mainpage.htm

\title{
Ethnochemistry of maguindanaons' on the usage of household chemicals: Implications to chemistry education
}

\author{
Norolayn K. Said-Ador \\ Mindanao State University- Institute of Science Education (Faculty) \\ Mindanao State University-Iligan Institute of Technology (Ph.D. Candidate)
}

\section{Abstract:}

Integrating ethnochemistry into the curriculum may provide students meaningful learning in addition to preservation and appreciation towards the quality of their cultural heritage. Hence, the study aimed to document the indigenous usage of household chemicals of Maguindanaons through ethnography research using purposive and snowball sampling in the selected municipalities of Maguindanao Province. Interview, Focus Group Discussion (FGD) and observation were employed for data collection in the five (5)-month community immersion. The data were then thematically analysed. As revealed, they had utilized substitutes for paint, floor polishers, mosquito repellents, bath and laundry soaps, toothpastes, perfumes, shampoo and other cosmetics. Furthermore, the study found out that their indigenous usage of household chemicals conforms to standard chemical bases. Accordingly, the output of the study may serve as groundwork to develop culture-based lessons in high school Chemistry in the said locale.

Keywords:

Ethnochemistry, chemistry education, culture-based lessons, household chemicals, Maguindanaons

Citation:

Said-Ador, Norolayn K. (2017); Ethnochemistry of Maguindanaons' on the usage of household chemicals: Implications to chemistry education; Journal of Social Sciences (COES\&RJ-JSS), Vol.6, No.2 Special, pp: 8-26. 


\section{Introduction}

Science educators continually quest for curriculum reforms to innovate the quality of education in the Philippines. This may serve as a challenge and even opportunity to explore and study all possible contributory factors affecting the performance of the students specifically those coming from the indigenous groups and other ethnic minorities. Maguindanaon is one of ethno-linguistic groups embracing an Islamic religion and majority of them occupy the Autonomous Region in Muslim Mindanao (ARMM) particularly Maguindanao Province.

Mangasakan (2007) performed a study on the status of high school chemistry teaching in Cotabato City, a former capital of Maguindanao Province. She found out that majority of the students had low achievement rating for the past years. There was a decrease in the academic performance of the city high school chemistry students. Besides, many chemistry teachers at the secondary level felt that students encountered difficulty in learning the basic chemistry concepts and principles. The students performed poorly in their periodical exams, lab works, and other classroom activities. Such finding is apart from some of the worse statistics indicating the poor performance of ARMM students in different assessments (NSO, 2008). And one of the barriers to quality education for Muslim learners is cultural insensitivity. Their needs are neglected and the contents of their books are not fit for them (SEAMEO, 2007).

With the foregoing dilemma, educators of the country have recurrently sought possible solutions to alleviate the condition. As a matter of fact, researches were already conducted to provide insights on how to confront the continuing low performance of the students in the country. Specifically, common assertion shows that students learn best when they can build on past experiences relevant to them and have direct "hands-on" involvement as well as construct their own knowledge. In view of that, science curriculum ought to be situated in the context of students' lives by addressing their cultural heritage as substance of scientific inquiry or explanation so that their attitude towards science tends to improve their academic performance. Furthermore, the acceptance of cultural knowledge and cultural differences leads to flexibility and innovation necessary for effective teaching and efficient learning. Learning becomes a meaningful engagement if it takes account of the learners' habitus (Shiza, 2005).

Likewise, the Department of Education (DepEd) has been committed to make education inclusive by adopting the National Indigenous Peoples Educational Policy Framework. It primarily aims to craft education culture-responsive (EFA, 2016). Moreover, the United States Agency for International Development (USAID, 2007) emphasized that it is imperative forteachers in public schools in Muslim communities to be oriented as well as be trainedfor cultural diversity, with particular focus on understanding the Muslim culture. Accordingly, the researcher was impelled to probe the ethnochemistry of Maguindanaons with respect to their indigenous usage of household chemicals. Household chemicals are chemicals typically found in household used for cleaning and general hygiene as well as coloring, pest and insect control. On the other side, ethnochemistry describes the chemical ideas and practices of a given culture (Singh \& Chibuye, 2016). Moreover, this study is anchored on the psychological and pedagogical roots with contextual basis. This may encompass constructivism (both cognitive and social) and situated learning. 
Ethnochemistry of maguindanaons on the usage of household chemicals ...

\section{Statement of the Problem}

The study aimed to investigate the ethnochemistry of Maguindanaons on their usage of household chemicals. Particularly, it sought to answer the questions: 1) What are their indigenoususages of household chemicals? 2) How do these conform to standard chemical bases? 3) What implications can be drawn from the study to Chemistry education?

\section{Significance of the Study}

The study's purpose on documenting the ethnochemistry of Maguindanaons with respect to their usage of household chemicals may benefit the tribe on appreciating and preserving the quality of their cultural heritage. In addition to that, curriculum makers and science teachers may also use the results and findings of the study as groundwork in developing a curriculum aligned to the culture, nature and needs of the group. Besides, the outcomes of the study may serve as fond of knowledge that may be a catalyst to build linkage between students' interest on consideration of their culture and their academic performance particularly in Chemistry class. The government may also possibly benefit from the study. It may gain useful insights on the indigenous knowledge of Maguindanaons which may assist them build more harmonious relationship. And the government may have a benchmark for policy implications specifically in relation to improve the performance of ARMM students.

\section{Research Design of the Study}

The study employed qualitative research design specifically using ethnographic techniques. The design is appropriate to probe the ethnochemistry of Maguindanaons on the household chemicals usage. The intact group was studied in their natural setting. Qualitative research explores issues, understands phenomena, and answers questions by analyzing and making sense of unstructured data. It involves the analysis of any unstructured data, including: open-ended survey responses, literature reviews, interviews, audio recordings, videos, pictures, social media and web pages (Onwuegbuzie, et. al., 2012).

\section{Sampling and Data Collection}

Purposive and snowball sampling were used to determine the research participants. The choice of specific barangays to immerse with from different municipalities of Maguindanao Province such as Sultan Kudarat, Datu-Odin Sinsuat, Datu-Piang, DatuSaudi and Buluan was based on accessibility and researcher's safety. Furthermore, through the assistance of gatekeepers, the key-informants and participants were selected using the inclusion criteria: 1) elders in the tribe who have had first-hand experience on the matter; and 2) knowledgeable residents who are either directly or indirectly involved with the usage of household chemicals.

Interview, Focus Group Discussion (FGD) and observation were used to gather the date in the five (5)-month community immersion.

\section{Treatment of Data}

The collected data from the household chemicals usage were analysed thematically. Thematic analysis may involve six phases: familiarizing with the data, generating initial codes, searching for themes, reviewing themes, defining and naming themes, and producing the report (Braun \& Clarke, 2006). To ensure the validity of data, triangulation method was utilized. Furthermore, informant checking and long term observations were carried-out. 
Subsequently, their indigenoususage of household chemicals was examined if it conforms to standard chemical bases revealed in several scientific researches.

\section{Findings of the Study}

Maguindanaons' indigenous usage of household chemicals has conformed to standard chemical bases. These household chemical substitutes for cleaning/washing, cosmetics, paint, floor wax/polisher, and mosquito repellents are revealed in Table 1.

\section{Table 1. Household Chemicals}

\begin{tabular}{|c|c|c|}
\hline CLEANING/WASHING & SUBSTITUTES & CHEMICAL BASES \\
\hline \multirow[t]{5}{*}{$\begin{array}{l}\text { Bath Soap } \\
\text { (rubbed on the skin) }\end{array}$} & $\begin{array}{l}\text { crushed tudi (Sesbania grandiflora) } \\
\text { leaves }\end{array}$ & $\begin{array}{l}\text { Indicated presence of phytochemicals } \\
\text { like saponins which have antibacterial } \\
\text { activity (Al-Dawah, et. al., 2014, } \\
\text { Yuswantina, et. al., 2016, } \\
\text { Padmalochana\&Rajan, 2014). Saponins } \\
\text { showed detergent properties } \\
\text { (Moghimipour\&Handali, 2014). }\end{array}$ \\
\hline & $\begin{array}{lll}\text { crushed } & \text { kasila } & \text { (Capsicum } \\
\text { frutescens) leaves } & \end{array}$ & $\begin{array}{l}\text { With presence of phytochemicals like } \\
\text { saponins with antibacterial (Ikpeme, et. } \\
\text { al., 2016) and antifungal (Soumya\& Nair, } \\
\text { 2012) properties. Also showed presence } \\
\text { of Vit. E (Ikpeme, et. al., 2016). }\end{array}$ \\
\hline & $\begin{array}{l}\text { crushed kapaya (Carica papaya) } \\
\text { leaves }\end{array}$ & $\begin{array}{l}\text { Showed presence of saponins with } \\
\text { antibacterial and antifungal properties } \\
\text { (Baskara, et. al., 2012, Suresh, et. al., } \\
\text { 2008, Sherwani, et al., 2013, Marshall, et. } \\
\text { al., 2015). Latex from leaves indicated } \\
\text { protelytic enzymes (papain) to soften and } \\
\text { dissolve dead skin layers, and strengthen } \\
\text { collagen tissue (Maregesi, et. al., 2014). } \\
\text { With Vit. E, glutathione peroxidase, } \\
\text { superoxide dismutase and catalase which } \\
\text { are skin care and whitening agents } \\
\text { (Asaolu, et. al., 2010). }\end{array}$ \\
\hline & $\begin{array}{l}\text { grated coconut (Cocos nucifera) } \\
\text { kernel }\end{array}$ & $\begin{array}{l}\text { Yielded oil with phytochemicals like } \\
\text { saponins (Sani, et. al., 2014, Obidoa, et. } \\
\text { al., 2010, Odenigbo\&Otisi, 2011) and } \\
\text { some fatty acids such as lauric acid and } \\
\text { palmitic acid with soap and } \\
\text { antibacterial/antifungal properties (da } \\
\text { Fonseca, et. al., 2014, Fife, 2000, Raj, et. } \\
\text { al., 2010). }\end{array}$ \\
\hline & $\begin{array}{l}\text { crushed sagiket (Ipomoea species) } \\
\text { leaves }\end{array}$ & $\begin{array}{l}\text { With phytochemicals like saponins } \\
\text { (Sahayaraj\& Ravi, } 2008 \text {, } \\
\text { Chandira\&Jayakar, 2010, Mungole, et. } \\
\text { al., 2010, Ganjir, et. al., 2013). Showed } \\
\text { antibacterial and antifungal properties } \\
\text { (Arora, et. al., 2013, Kumar, et. al., } \\
\text { 2016). }\end{array}$ \\
\hline $\begin{array}{l}\text { Laundry Soap } \\
\text { (mixed with the cloth } \\
\text { and/or water for washing) }\end{array}$ & extracts from citrus fruits & $\begin{array}{l}\text { Contained essential oils, majority of } \\
\text { which is limonene (Chanthaphon, et. al., } \\
\text { 2008, Colecio-Juarez, et. al., 2012, } \\
\text { Mohammed, et. al., 2013). Limonene has } \\
\text { cleaning potential (Peters, 1994, Hansen, } \\
\text { et. al., 1995, Lu, et. al., 2000). }\end{array}$ \\
\hline
\end{tabular}


Ethnochemistry of maguindanaons on the usage of household chemicals ...

\begin{tabular}{|c|c|c|}
\hline & $\begin{array}{l}\text { extract from } \\
\text { lapitos(Averrhoabilimbi) fruit }\end{array}$ & $\begin{array}{l}\text { With the presence of saponins } \\
\text { (Hasanuzzaman, et. al., 2013, Kumar, et. } \\
\text { al., 2013, Abraham, 2016). Positive for } \\
\text { citric acid Kumar, et. al., 2013, Abraham, } \\
\text { 2016) and oxalic acid (Hasim, 2014) } \\
\text { which have bleaching and cleaning } \\
\text { properties (Dangat, et. al., 2014). }\end{array}$ \\
\hline $\begin{array}{l}\text { Bleach } \\
\text { (mixed with the cloth } \\
\text { and/or water for washing) }\end{array}$ & extract from citrus fruits & $\begin{array}{l}\text { Contained essential oils, majority of } \\
\text { which is limonene (Chanthaphon, et. al., } \\
\text { 2008, Colecio-Juarez, et. al., 2012, } \\
\text { Mohammed, et. al., 2013). Limonene has } \\
\text { cleaning potential (Peters, 1994, Hansen, } \\
\text { et. al., 1995, Lu, et. al., 2000). Showed } \\
\text { presence of citric acid which has natural } \\
\text { bleaching property (Maregesi, et. al., } \\
\text { 2014). }\end{array}$ \\
\hline COSMETICS & SUBSTITUTES & CHEMICAL BASES \\
\hline $\begin{array}{l}\text { Toothpaste } \\
\text { (used as mouthwash } \\
\text { and/or paste or being } \\
\text { chewed if bama is } \\
\text { utilized) }\end{array}$ & timos (table salt) & $\begin{array}{l}\text { Salt restricts bacterial growth; it may } \\
\text { temporarily change the } \mathrm{pH} \text { of the mouth } \\
\text { and it also absorbs water molecules } \\
\text { (Dubois, 2013). }\end{array}$ \\
\hline & $\begin{array}{l}\text { bama (betel quid containing betel } \\
\text { leaf, areca nut, tobacco and slaked } \\
\text { lime) }\end{array}$ & $\begin{array}{l}\text { Betel leaf contained phenolic compounds } \\
\text { such as chavicol and allylpyrocatechol } \\
\text { (Paridhi, et. al., 2015, Bajpai, et. al., } \\
2010 \text { ) with antibacterial property } \\
\text { (Paridhi, et. al., 2015, Datta, et. al., 2011, } \\
\text { Akter, et. al., 2013). Areca nut has } \\
\text { astringent properties due to presence of } \\
\text { polyphenols (IARC, 2004, Patil, et. al., } \\
\text { 2009). Tobacco contained toxic alkaloid } \\
\text { nicotine and large amount of salts } \\
\text { (Quisumbing, 1978) which may account } \\
\text { for its antibacterial property (Rawat\& } \\
\text { Mali, 2013). Slaked lime (CaOH) } \\
\text { provides alkaline condition (Sazwi, et. } \\
\text { al., 2013) which may deter bacterial } \\
\text { growth. }\end{array}$ \\
\hline \multirow[t]{3}{*}{$\begin{array}{l}\text { Shampoo } \\
\text { (rubbed on the scalp and } \\
\text { hair) }\end{array}$} & $\begin{array}{l}\text { extracted coconut (Cocos nucifera) } \\
\text { milk }\end{array}$ & $\begin{array}{l}\text { Yielded oil (Sani, et. al., 2014) which } \\
\text { may lubricate, make hair shiny, and } \\
\text { reduce hair breakage. It has antibacterial } \\
\text { and antifungal properties (Fife, 2000, } \\
\text { Oyi, et. al., 2016). }\end{array}$ \\
\hline & $\begin{array}{l}\text { coconut milk mixed with } \\
\text { bulok(Ocimum species) }\end{array}$ & $\begin{array}{l}\text { Extract from Ocimum species may give } \\
\text { fragrance. }\end{array}$ \\
\hline & $\begin{array}{l}\text { coconut milk mixed with } \\
\text { balili(Eleusineindica) }\end{array}$ & $\begin{array}{l}\text { Eleusineindica contained phytochemicals } \\
\text { such as saponins, polyphenols, sterols } \\
\text { and/or triterpenes, steroids, and } \\
\text { flavonoids which have antimicrobial } \\
\text { properties (Mabeku, et. al., 2011). }\end{array}$ \\
\hline
\end{tabular}


Journal of Social Sciences (COES\&RJ-JSS), 6(2) Special, pp. 8-26

\begin{tabular}{|c|c|c|}
\hline & extract from sapal (Sida species) & $\begin{array}{l}\text { Indicated the presence of phytochemicals } \\
\text { such as alkaloids, flavonoids, steroids, } \\
\text { tannins, phenols, and terpenoids } \\
\text { (Adeniyi, et. al., 2016, } \\
\text { Narendhirakannan\&Limmy, 2010, } \\
\text { Logeswari, et. al., 2013) which have } \\
\text { insecticidal (Adeniyi, et. al., 2016) and } \\
\text { antibacterial (Woldeyes, et. al, 2012, } \\
\text { Karou, et. al., 2005) properties. }\end{array}$ \\
\hline \multirow[t]{6}{*}{$\begin{array}{l}\text { Face Powder } \\
\text { (applied on the face and } \\
\text { may be used as face mask } \\
\text { overnight) }\end{array}$} & Pinilo (grounded and soaked rice) & $\begin{array}{l}\text { Rice contained moisture, Vit. B-complex, } \\
\text { and Vit. E. (Umadevi, et. al., 2012, } \\
\text { Koeler\&Wieser, 2013). It is also positive } \\
\text { for ceramide (Lati, 1995) and ferulic acid } \\
\text { (Ferulic Acid, 2016). These are beneficial } \\
\text { to skin protection and nourishment. }\end{array}$ \\
\hline & mixed with eggs & $\begin{array}{l}\text { Source of ceramides (Vesper, et. al., } \\
\text { 1999)which prevent moisture loss } \\
\text { (Imokawa, 1995) and promote a pigment } \\
\text { lightening effect (Motta, et. al., 1993). } \\
\text { Eggs have binding property and } \\
\text { contained proteins such as lysozome, } \\
\text { conalbumin, avidin, ovoflavoprotein, and } \\
\text { etc; these have antibacterial property (ul- } \\
\text { Haq\&ur-Rehman, 2004). }\end{array}$ \\
\hline & $\begin{array}{l}\text { mixed with kisul } \\
\text { (Kaempferiagalanga) } \\
\text { leaf extract }\end{array}$ & $\begin{array}{l}\text { Indicated the presence of essential oils } \\
\text { which have antibacterial, antifungal and } \\
\text { antioxidant activities (Rao, et. al., 2009, } \\
\text { Tewtrakul, et. al., 2005). }\end{array}$ \\
\hline & $\begin{array}{l}\text { mixed with kasila } \\
\text { (Capsicum frutescens) } \\
\text { leaf extract }\end{array}$ & $\begin{array}{l}\text { With presence of phytochemicals like } \\
\text { saponins, tannins, flavonoids, alkaloids } \\
\text { and phenols with antibacterial (Ikpeme, } \\
\text { et. al., 2016) and antifungal (Soumya\& } \\
\text { Nair, 2012) properties. Also showed } \\
\text { presence of Vit. E (Ikpeme, et. al., 2016). }\end{array}$ \\
\hline & $\begin{array}{l}\text { mixed with } t u d i \\
\text { (Sesbania grandiflora) } \\
\text { leaf extract }\end{array}$ & $\begin{array}{l}\text { Indicated presence of phytochemicals } \\
\text { like saponins, flavonoids, tannins, and } \\
\text { alkaloids which have antibacterial } \\
\text { activity (Al-Dawah, et. al., 2014, } \\
\text { Yuswantina, et. al., 2016, } \\
\text { Padmalochana\&Rajan, 2014). }\end{array}$ \\
\hline & $\begin{array}{l}\text { mixed with kapaya } \\
\text { (Carica papaya) } \\
\text { leaf extract }\end{array}$ & $\begin{array}{l}\text { Showed presence of saponins, alkaloids, } \\
\text { tannins, and flavonoids with antibacterial } \\
\text { and antifungal properties (Baskara, et. al., } \\
\text { 2012, Suresh, et. al., 2008, Sherwani, et. } \\
\text { al., 2013, Marshall, et. al., 2015). Latex } \\
\text { from leaves indicated protelytic enzymes } \\
\text { (papain) to soften and dissolve dead skin } \\
\text { layers, andstrengthen collagen tissue } \\
\text { (Maragesi, et. al., 2014). With Vit. E, } \\
\text { glutathione peroxidase, superoxide } \\
\text { dismutase and catalase (Asaolu, et. al., } \\
\text { 2010). }\end{array}$ \\
\hline
\end{tabular}


Ethnochemistry of maguindanaons on the usage of household chemicals ...

\begin{tabular}{|c|c|c|}
\hline & $\begin{array}{l}\text { mixed with balikakab } \\
\text { (Naucleaorientalis) } \\
\text { leaf extract }\end{array}$ & $\begin{array}{l}\text { With augustine alkaloids with } \\
\text { antibacterial property (Talib, 2010). It } \\
\text { also contains oleanic acid which } \\
\text { exhibited antioxidant activity (Deharo\& } \\
\text { Ginsburg, 2011). }\end{array}$ \\
\hline & $\begin{array}{l}\text { mixed with kalamunding } \\
\text { (Citrus microcarpa) } \\
\text { fruit extract }\end{array}$ & $\begin{array}{l}\text { Showed presence of essential oils such as } \\
\text { limonene, myrcene, linalool and a- } \\
\text { terpineol (Jantan, et. al., 1996). With } \\
\text { flavonoids, hesperidine, total phenolic } \\
\text { contents which have antioxidant and } \\
\text { antimicrobial activities (Ghafar, et. al., } \\
\text { 2010). }\end{array}$ \\
\hline \multirow[t]{2}{*}{ Lipstick } & $\begin{array}{lll}\text { powder from } & \text { galuga } \\
\text { (Bixaorellana) } & & \end{array}$ & $\begin{array}{l}\text { Reddish orange color comes from the } \\
\text { resinous outer covering of the seed } \\
\text { having carotenoid pigments bixin, } \\
\text { norbixin and their esters (Sainath, et. al., } \\
\text { 2016, Chengaiah, 2010). }\end{array}$ \\
\hline & talu (beeswax) & $\begin{array}{l}\text { Composed of esters of wax acids, } \\
\text { hydrocarbons, free wax acids, cholesteryl } \\
\text { esters of fatty acids, and moisture } \\
\text { (Herman, 1998). It has binding property } \\
\text { and provides creamy texture and good } \\
\text { adhesion to skin (Endlein\&Peleikis, } \\
\text { 2011). }\end{array}$ \\
\hline Eyebrow Pencil & burned kupras(copra) & $\begin{array}{l}\text { Copra contains moisture, ash, crude fats, } \\
\text { crude protein, crude fiber and } \\
\text { carbohydrates (Ghosh, et. al., 2014). } \\
\text { Once burned, the copra turns to black } \\
\text { pigment. }\end{array}$ \\
\hline \multirow[t]{2}{*}{ Nail Polish/Coloring } & patyal (henna) & $\begin{array}{l}\text { With the presence of lawsone (red orange } \\
\text { dye) (Musa \&Gasmelseed, 2012). }\end{array}$ \\
\hline & galuga (Bixaorellana) & $\begin{array}{l}\text { Reddish orange color comes from the } \\
\text { resinous outer covering of the seed } \\
\text { having carotenoid pigments bixin, } \\
\text { norbixin and their esters (Sainath, et. al., } \\
\text { 2016, Chengaiah, et. al., 2010). }\end{array}$ \\
\hline \multirow[t]{3}{*}{ Skin Creams/Lotions } & $\begin{array}{l}\text { grated coconut (Cocos nucifera) } \\
\text { meat/kernel }\end{array}$ & $\begin{array}{l}\text { Yielded oil with phytochemicals like } \\
\text { saponins, alkaloids, flavonoids, and } \\
\text { tannins (Sani, et. al., 2014, Obidoa, et. } \\
\text { al., 2010, Odenigbo\&Otisi, 2011) and } \\
\text { some fatty acids with } \\
\text { antibacterial/antifungal properties (da } \\
\text { Fonseca, 2014, Fife, 2000, Raj, et. al., } \\
\text { 2010). } \\
\text { Oil has emollient property which softens } \\
\text { skin by preventing water loss (Jones } \\
\text { \&Selinger, 2016). }\end{array}$ \\
\hline & $\begin{array}{l}\text { coconut milk mixed } \quad \text { with } \\
\text { bulok(Ocimum species) }\end{array}$ & $\begin{array}{l}\text { Ocimum species contained essential oils } \\
\text { which may provide fragrance. }\end{array}$ \\
\hline & $\begin{array}{l}\text { penggawb (steam bath using } \\
\text { mixture of water and extracts of } \\
\text { citrus fruit peelings and/or leaves); } \\
\text { frequently practiced before }\end{array}$ & $\begin{array}{l}\text { Citrus fruits have essential oils such as } \\
\text { limonene, sabinene, citronellal, linalool } \\
\text { and hedycaryol which have antibacterial } \\
\text { property (Othman, et. al., 2016). They }\end{array}$ \\
\hline
\end{tabular}


Journal of Social Sciences (COES\&RJ-JSS), 6(2) Special, pp. 8-26

\begin{tabular}{|c|c|c|}
\hline & women's wedding & $\begin{array}{l}\text { have antioxidant activities (Ghafar, et. al., } \\
\text { 2010). These may soften skin and } \\
\text { eliminate body odor (Dassanayake, } \\
\text { 1985). }\end{array}$ \\
\hline & $\begin{array}{l}\text { crushed leaves of sagiket (Ipomoea } \\
\text { species) as sunblock }\end{array}$ & $\begin{array}{l}\text { Indicated the presence of } \\
\text { phytochemicals such as flavonoids, } \\
\text { phenolics, and tannins (Sahayaraj\& Ravi, } \\
\text { 2008, Mungole, et. al., 2010, Arora, et. } \\
\text { al., 2013) which have UV absorbing } \\
\text { activity (Khazaeli \& Mehrabani, 2008, } \\
\text { Donglikar\&Deore, 2016, Gupta, 2016). }\end{array}$ \\
\hline \multirow[t]{9}{*}{$\begin{array}{l}\text { Perfume } \\
\text { (leaves and/or flowers } \\
\text { inserted between folded } \\
\text { cloths) }\end{array}$} & bulok (Ocimum species) leaves & $\begin{array}{l}\text { Showed presence of essential oils such as } \\
\text { linalool, geraniol, 1,8-cineole, eugenol } \\
\text { and methyl chavicol (Oliveira, et. al., } \\
2009 \text {, Abduelrahman, et. al., 2009, Imeri, } \\
\text { et. al., 2014) which are responsible for its } \\
\text { fragrance. }\end{array}$ \\
\hline & $\begin{array}{l}\text { magrib (Cestrum nocturnum) } \\
\text { flowers and leaves }\end{array}$ & $\begin{array}{l}\text { Indicated presence of essential oils such } \\
\text { as linalool, benzyl alcohol, phenyl } \\
\text { acetaldehyde, cis-jasmone, benzyl } \\
\text { acetate, and etc. (Kaul, et. al., 1995). }\end{array}$ \\
\hline & $\begin{array}{l}\text { oliganu/kapal (Coleus amboinicus) } \\
\text { leaves }\end{array}$ & $\begin{array}{l}\text { With presence of essential oils such as } \\
\text { carvacrol, thymol, eugenol, chavicol, and } \\
\text { ethyl salicylate (Saraswati, et. al., 2016). }\end{array}$ \\
\hline & $\begin{array}{l}\text { giampaka (Micheliae } \\
\text { flowers and leaves }\end{array}$ & $\begin{array}{l}\text { Showed presence of essential oils such as } \\
\text { linalool, phenyl ethyl alcohol, and indole } \\
\text { (Punjee, et. al., 2009). }\end{array}$ \\
\hline & $\begin{array}{l}\text { malul/lumabi (Jasminumsambac) } \\
\text { flowers }\end{array}$ & $\begin{array}{l}\text { With essential oils such as linalool, } \\
\text { benzyl acetate, } \alpha \text { - farnesene, benzyl } \\
\text { alcohol, and cis-jasmone (Lourith, et. al., } \\
\text { 2013, Sabharwal, et. al., 2013). }\end{array}$ \\
\hline & $\begin{array}{l}\text { kalasutsi(Plumeriaacuminata) } \\
\text { flowers }\end{array}$ & $\begin{array}{l}\text { Indicated presence of essential oils such } \\
\text { as geraniol, citronellol, farnesol, and } \\
\text { phenyl ethyl alcohol (Choudhary, et. al., } \\
\text { 2014, Farooque, et. al., 2012). }\end{array}$ \\
\hline & $\begin{array}{l}\text { langilang } \quad \text { (Canagiumodoratum) } \\
\text { flowers }\end{array}$ & $\begin{array}{l}\text { Showed presence of essential oils such as } \\
\text { linalool, p-cresyl, methyl ether (p-methyl } \\
\text { anisole), benzyl acetate, geranyl acetate } \\
\text { (Tan, et. al., 2015). }\end{array}$ \\
\hline & sabi (Chenopodiumambrosiodes) & $\begin{array}{l}\text { With presence of essential oils such as } \\
\text { ascaridol, p-cymene, neral, geraniol, } \\
\text { carvacrol, and } \alpha \text {-terpinene (Koba, et. al., } \\
\text { 2009). }\end{array}$ \\
\hline & kisul(Kaemperiagalanga) & $\begin{array}{l}\text { Indicated presence of essential oils such } \\
\text { as ethyl cinnamate, ethyl-p- } \\
\text { methoxycinnamate, n-pentadecane, } \alpha \text { - } \\
\text { cadinene, } 1,8 \text {-cineole, } \alpha \text {-gurjunene, and } \\
\beta \text {-sinensal (Rao, et. al., 2009). }\end{array}$ \\
\hline $\begin{array}{l}\text { Underarm Deodorants } \\
\text { (rubbed on the armpit) }\end{array}$ & apog (slaked lime) & $\begin{array}{l}\text { Made from calcium hydroxide which has } \\
\text { high } \mathrm{pH} \text {; its ions act on tissues and }\end{array}$ \\
\hline
\end{tabular}


Ethnochemistry of maguindanaons on the usage of household chemicals ...

\begin{tabular}{|c|c|c|}
\hline & & bacteria (Estrella \& Holland, 2003). \\
\hline & $\begin{array}{l}\begin{array}{l}\text { crushed leaves of bayabas } \\
\text { (Psidiumguajava) }\end{array} \\
\end{array}$ & $\begin{array}{l}\text { Main constituents are phenolic } \\
\text { compounds, isoflavonoids, gallic acid, } \\
\text { catechin, epicatechin, lutin, naringenin, } \\
\text { and kaempferol (BArbalho, et. al., 2012). } \\
\text { Showed antibacterial property } \\
\text { (Nascimento, et. al., 2000, Goncalves, et. } \\
\text { al., 2008). }\end{array}$ \\
\hline & $\begin{array}{l}\text { crushed leaves } \\
\text { bayabanu/balibanu } \\
\text { (Anonamauricata) }\end{array}$ & $\begin{array}{l}\text { With the presence of alkaloids, } \\
\text { flavonoids, tannins, and high phenol } \\
\text { content, Vit. C and Vit. E. which possess } \\
\text { antibacterial property (Vijayameena, et. } \\
\text { al., 2013). It also showed } \\
\text { annonaceousacetogenins as the major } \\
\text { phytochemical constituent and it has } \\
\text { pesticidal activity (Moghadamtousi, et. } \\
\text { al., 2015). }\end{array}$ \\
\hline & $\begin{array}{l}\text { crushed leaves of kapaya (Carica } \\
\text { papaya) }\end{array}$ & $\begin{array}{l}\text { Showed presence of phytochemicals such } \\
\text { as alkaloids, tannins, flavonoids and } \\
\text { saponins with antibacterial and antifungal } \\
\text { properties (Baskara, et. al., 2012, Suresh, } \\
\text { et. al., 2008, Sherwani, et. al., 2013, } \\
\text { Marshall, et. al., 2015). With Vit. E, } \\
\text { glutathione peroxidase, superoxide } \\
\text { dismutase and catalase which are skin } \\
\text { care and whitening agents (Asaolu, et. al., } \\
\text { 2010). }\end{array}$ \\
\hline & $\begin{array}{l}\text { crushed leaves of } \\
\text { kalamunding(Citrus microcarpa) }\end{array}$ & $\begin{array}{l}\text { Indicated presence of essential oils such } \\
\text { as limonene, myrcene, linalool and } \alpha- \\
\text { terpineol(Jantan, et. al., 1996). With } \\
\text { flavonoids, hesperidine, total phenolic } \\
\text { contents which have antioxidant and } \\
\text { antimicrobial activities (Ghafar, et. al., } \\
\text { 2010). }\end{array}$ \\
\hline PAINT & SUBSTITUTE & CHEMICAL BASIS \\
\hline (арриlea & $\begin{array}{lll}\text { powder } & \text { from } & \text { galuga } \\
\text { (Bixaorellana) } & \text { seeds } & \end{array}$ & $\begin{array}{l}\text { Reddish orange color comes from the } \\
\text { resinous outer covering of the seed } \\
\text { having carotenoid pigments bixin, } \\
\text { norbixin and their esters (Sainath, et. al., } \\
\text { 2016, Chengaiah, et. al., 2010). }\end{array}$ \\
\hline FLOOR & SUBSTITUTES & CHEMICAL BASES \\
\hline WAX/POLISHER & $\begin{array}{l}\text { grated coconut (Cocos nucifera) } \\
\text { kernel }\end{array}$ & $\begin{array}{l}\text { Kernel yielded oil (Sani, et. al., 2014) } \\
\text { making the floor shiny. }\end{array}$ \\
\hline & saging (Musa sapientum) leaves & $\begin{array}{l}\text { Yielded wax from the lipid fraction with } \\
\text { fatty acids having carbon numbers } \\
\text { ranging from C14 to C30 in which C22 is } \\
\text { the most abundant (Yanagida, 2003). }\end{array}$ \\
\hline MOSQUITO & SUBSTITUTES & CHEMICAL BASES \\
\hline $\begin{array}{l}\text { REPELLENT } \\
\text { (parts of the plants are } \\
\text { burned to produce smoke) }\end{array}$ & $\begin{array}{l}\text { smoke from } \\
\text { katol(Azadirachtaindica) leaves }\end{array}$ & $\begin{array}{l}\text { Showed the presence of azadirachtin } \\
\text { which is the main component for toxic } \\
\text { effects against insects (Mordue\&Nisbet, } \\
\text { 2000, Roy \&Saraf, 2005). }\end{array}$ \\
\hline
\end{tabular}




\begin{tabular}{|l|l|l|}
\hline & $\begin{array}{l}\text { smoke from famasi } \\
\text { (Artocarpuscamansi) flowers }\end{array}$ & $\begin{array}{l}\text { With the presence of sapotoxin which is } \\
\text { responsible for its repellent activity } \\
\text { (Hadiyoana, et. al., 2011). }\end{array}$ \\
\cline { 2 - 4 } & $\begin{array}{l}\text { smoke from } \\
\text { buwan(Lansiumdomesticum fruit } \\
\text { peelings }\end{array}$ & $\begin{array}{l}\text { Indicated the presence of triterpene } \\
\text { glycosides and seco-onoceranoids such as } \\
\text { lansic acid which can be attributed to its } \\
\text { toxicity (Nishizawa, et. al., 1983). Also } \\
\text { showed rich in tannins (Monzon, et. al., } \\
\text { 2016) and high alkaloids (Solidum, 2012) } \\
\text { which have larvicidal potential. }\end{array}$ \\
\hline
\end{tabular}

As shown, almost all substitutes are plant-based. These plants contain phytochemicals and/or essential oils accountable for their cleaning, whitening, dyeing, fragrance, antioxidant, antimicrobial and insecticidal potentials as supported by several studies. Maguindanaons have used and developed substitutes derived from resources available in their locality.

However, with the advent of modern technology, they have shifted to using commercial products due to convenience. But, some old folks particularly those residing in remote areas are still utilizing some substitutes.If using household chemical substitutes gradually diminishes, the new Maguindanaon generation may hardly recognize their ethnochemistry with respect to this. Hence, incorporating this into the curriculum may help students appreciate and preserve their cultural heritage. Additionally, it may bring relevant learning which may eventually improve their academic performance. In the K-12 curriculum, this household chemicals usage can be integrated in the discussion of high school chemistry on organic compounds and biomolecules. Students may attain the learning competencies such as recognizing the general classes of organic compounds as well as their uses and learning the major categories of biomolecules such as carbohydrates, lipids, proteins, and nucleic acids. Aside from that, students may easily understand some of the biochemical reactions by using the concepts acquired from their own ethnochemistry.

\section{Conclusion and Implication of the Study}

Maguindanaons utilized substitutes for bath and laundry soaps, bleach, paint, floor wax, mosquito repellents, toothpaste, perfumes, shampoo, and other cosmetics. Their indigenoususage of household chemicals has standard chemical bases as revealed in several researches conducted. And their ethnochemistrycan be integrated in high school chemistry which may not only bring meaningful learning to students but may also make them appreciate and preserve their cultural heritage.

Accordingly, Chemistry educators may design a curriculum aligned to the ethnochemistry of Maguindanaons. Culture-based lessons may be developed and implemented to high schools in the province of Maguindanao. And evaluation may be conducted to assess its effectiveness in terms of students' motivation and achievement including critical and other thinking skills for further researches.

\section{References}

Abduelrahman, A., et al. (2009). Morphological Variability and Chemical Composition of Essential Oils from Nineteen Varieties of Basil Growing in Basil.International Journal of Technology. Retrieved from http://scialert.net/qredirect.php?doi=ijct.2009.1.10\&linkid=pdf on December 15, 2016. 
Abraham, C. (2016). A Study on Phytochemical Constituents of Averrhoabilimbi.Indian Journal of Applied Research.Retrieved from http://www.worldwidejournals.in/ojs/index.php/ijar/article/view/10299 on December 12, 2016.

Adeniyi, S., et al. Preliminary Phytochemical Analysis and Insecticidal Activity of Ethanolic Extracts of Four Tropical Plants against Beans Weevil. International Journal of the Physical Sciences.Retrieved from http://www.academicjournals.org/journal/IJPS/article-full-text-pdf/CA0348A26825 on December 18, 2016.

Akter, K., et al. (2013). Evaluation of Antibacterial and Anthelmintic Activities with Total Phenolic Contents of Piper betel Leaves. Avicenna Journal of Phytomedicine.Retrieved from http://ajp.mums.ac.ir/pdf_2777_0d0d9a7c2b8b7bd216ecdb13c2890c40.html on December 20, 2016.

Al-Dawah, N., et al. (2014). Comparative of Phytochemical and Antimicrobial of Sesbania grandiflora Leaves Extract. Medical Journal of Babylon.vol.11 no.3.Retrieved from http://www.medicaljb.com/library/paper/11_3_894.pdf on December 4, 2016.

Arora, S., et al. (2013).Phytochemical, Antimicrobial, and Antioxidant Activities of Methanol Extracts of Leaves and Flowers of Ipomoea cairica.International Journal of Pharmacy and Pharmaceutical Sciences.Retrieved from http://www.ijppsjournal.com/Vol5Issue1/6163.pdf on December 9, 2016.

Asaolu, M. et al. (2010). Evaluation of Phytochemicals and Antioxidants of Four Botanicals with Antihypertensive Properties.International Journal of Pharma and Bio Sciences.Retrieved from http://ijpbs.net/issue-2/112.pdf on December 7, 2016.

Bajpai, V., et al. (2010). Profiling of Piper betle Cultivars by Direct Analysis in Real Time Mass Spectrometric Techniques.Biomedical Chromatography.Retrieved from http://onlinelibrary.wiley.com/doi/10.1002/bmc.1437/pdf on December 20, 2016.

Barbalho, S., et al. (2012). PsidiumGuajava (Guava): A Plant of Multipurpose Medicinal Applications. Medicinal and Aroamtic Plants.Retrieved from https://www.omicsgroup.org/journals/psidium-guajava-guava-a-plant-of-multipurposemedicinal-applications-2167-0412.1000104.php?aid=6652 on December 20, 2016.

Baskara, C. et al. (2012). The Efficacy of Carica papaya Leaf Extract on some Bacterial and Fungal Strain by Well Diffusion Method.Asian Pacific Journal of Tropical Disease.Retrieved from http://www.apjtcm.com/zz/2012s2/22.pdf on December 6, 2016.

Braun, V. and Clarke, V. (2006). Using Thematic Analysis in Psychology.Qualitative Research in Psychology.Retrieved from http://eprints.uwe.ac.uk/11735 on February 5, 2016.

Chandira, M and Jayakar, B. (2010). Formulation and Evaluation of Herbal Tablets Containign Ipomoea digitata Extract. International Journal of Pharmaceutical Sciences Review and Research.Retrieved from http://www.globalresearchonline.net/journalcontents/volume3issue1/Article\%20022.pdf on December 9, 2016.

Chanthaphon, S., et. al. (2008). Antimicrobial Activities of Essential Oils and Crude Extracts from Tropical Citrus spp. Against Food-Related Microorganisms. Retrieved from http://rdo.psu.ac.th/sjstweb/journal/30-Suppl-1/0125-3395-30-S1-125-131.pdf on December 9, 2016.

Chengaiah, B., et al. (2010). Medicinal Importance of Natural Dyes- A Review.International Journal of PharmTech Research.Retrieved from 
http://sphinxsai.com/sphinxsaivol_2no.1/pharmtech_vol_2no.1/PharmTech_Vol_2No.1P DF/PT=24\%20(144-154).pdf on December 15, 2016.

Choudhary, M., et al. (2014). Phytochemical and Pharmacological Activity of Genus Plumeria: An Updated Review. International Journal of Biomedical and Advance Research.Retrieved from http://ssjournals.com.md-in1.webhostbox.net/index.php/ijbar/article/view/512 on December 16, 2016.

Colecio-Juarez, M., et al. (2012).Characterization of Volatile Compounds in the Essential Oil of Sweet Lime.Chilean Journal of Agricultural Research.Retrieved from http://search.proquest.com/central/docview/1291056837/fulltextPDF/B2792E5632524E43 PQ/17? accountid=141440 on December 9, 2016.

da Fonseca, A., et al. (2014). Fatty Chemical Composition and Antioxidant Activities of Coconut Oils (Cocos nucifera).Journal of Medicinal Plant Research.Retrieved from http://www.academicjournals.org/journal/JMPR/article-full-text-pdf/72F27EE47406 on December 8, 2016.

Dangat, B., et. al. (2014). Mineral Analysis of Averrhoabilimbi- A Potential Fruit.Asian Journal of Pharmaceutical and Clinical Research.Retrieved from http://www.innovareacademics.in/journals/index.php/ajpcr/article/view/1242 on December 11, 2016.

Dassanayake, M. (1985). A Revised Handbook to the Flora of Ceylon. Amerind Publishing Co., Ltd. New Delhi, India.

Datta, A., et al. (2011). Antimicrobial Property of Piper betel Leaf against Clinical Isolates of Bacteria.International Journal of Pharma Sciences and Research.Retrieved from http://www.ijpsr.info/docs/IJPSR11-02-03-05.pdf on December 20, 2016.

Deharo, E. and Ginsburg, H. (2011). Analysis of Additivity and Synergism in the Antiplasmodial Effect of Purified Compounds from Plant Extracts.Malaria Journal.Retrieved from

http://search.proquest.com/central/docview/902240237/C647DB2B10824110PQ/17?acco untid=141440 on December 10, 2016.

Donglikar, M. and Deore, S. (2016). Sunscreens: A Review. Pharmacognosy Journal.Retrieved from http://www.phcogfirst.com/phcogj on December 21, 2016.

Dubois, S. (2013). The Use of Salt Water for Washing the Mouth.Retrieved from http://www.livestrong.com/article/547267-the-use-of-salt-water-for-washing-the-mouth/ on December 14, 2016.

Education for All 2015 National Review Report: Philippines. Retrieved from http://unesdoc.unesco.org/images/0023/002303/230331e.pdf on March 20, 2016.

Endlein, E. and Peleikis, K. (2011). Natural Waxes: Properties, Compositions, and Applications. SOFW Journal.Retrieved from https://www.kahlwax.de/fileadmin/downloads/SOFW_Journal_4_2011.pdf on December 20, 2016.

Estrela, C. and Holland, R. (2003). Calcium Hydroxide :Study Based on Scientific Evidences. Journal of Applied Oral Science.Retrieved from http://www.scielo.br/pdf/jaos/v11n4/a01v11n4.pdf on December 20, 2016.

Farooque, A., et al. (2012). A Review on Plumeriaacuminata.International Journal of Research Pharmacy and Chemistry.Retrieved from http://www.ijrpc.com/files/31-264.pdf on December 16, 2016.

Ferulic Acid.Oryza Oil and Fat Chemical Co., Ltd. Retrieved from http://www.oryza.co.jp/html/english/pdf/Ferulic_acid_1.1M.pdf on December 18, 2016.

Fife, B. (2000). The Healing Miracles of Coconut Oil. Piccadilly Books Ltd., Healthwise Publications, Colorado Springs, Co. pp 1-46. 
Ganjir, M., et al. (2013).Phytochemical Analysis, Cytotoxic and Antioxidant Potential of Ipomoea pes caprae and Merremia umbellate.International Journal of Scientific and technology Research. Retrieved from http://www.ijstr.org/finalprint/may2013/Phytochemical-Analysis-Cytotoxic-And-Antioxidant-Potential-OfIpomoea-Pes-Capraelr.br-And-Merremia-Umbellatal.h.-Hallier..pdf on December 9, 2016. Ghafar, M. et al. (2010). Flavonoid, Hesperidine, Total Phenolic Contents and Antioxidant Activities from Citrus species. African Journal of Biotechnology.Retrieved from http://www.ajol.info/index.php/ajb/article/view/77908/68305 on December 20, 2016. Ghosh, P., et al. (2014). Physicochemical and Phytochemical Analysis of Copra and Oil of Cocos nucifera.Hindawi Publishing Corporation. Retrieved from https://www.hindawi.com/journals/ijfs/2014/310852/ on December 20, 2016.

Goncalves, F., et al. (2008). Antibacterial Activity of Guava Leaf Extracts on DiarrheaCausing Enteric Bacteria Isolate from Seabob Shrimp. Rev. Inst. Med. Trop. Retrieved from http://www.scielo.br/pdf/rimtsp/v50n1/a03v50n1.pdf on December 20, 2016.

Gupta, V. (2016). Phytochemcial Analysis and UV Protective Property of Psidiumguajava Leaves Extract.Agricultural Science.Retrieved from http://worldwidejournals.in/ojs/index.php/gjra/article/view/1945 on December 10, 2016.

Hadiyoana, D., et al. (2011). Repellent Activity of Bio-active Agent from

ArtocarpuscamansiagainstAe.Aegypti. Retrieved from

http://s3.amazonaws.com/academia.edu.documents/33002303/Repellent_Activity_of_Bioactive_Agent_from_Artocarpus_camansi_against_Ae._Aegypti.pdf?AWSAccessKeyId= AKIAJ56TQJRTWSMTNPEA\&Expires=1482652889\&Signature=5994YGDM9nRc4wo nJM1AUHktbx8\%3D\&response-content-

disposition=inline\%3B\%20filename\%3DRepellent_Activity_of_Bio-active_Agent_f.pdf on December 20, 2016.

Hansen, K., et al. (1995). Dusting and Cleaning Composition.United States Patent.Retrieved from https://www.google.com/patents/US5399282 on December 10, 2016.

Hasanuzzaman, et al. (2013) Evaluation of Total Phenolic Content, Free Radical Scavenging Activity and Phytochemical Screening of Different Extracts of Averrhoabilimbi.International Current Pharmaceutical Journal.Retrieved from http://www.banglajol.info/bd/index.php/ICPJ/article/view/14058 on December 10, 2016.

Hasim, N. (2014). Study on Bioactive Compound DegradationfromBelimbingBuluh. Undergraduate Thesis.Universiti Malaysia Pahang.Retrieved from http://umpir.ump.edu.my/9138/1/cd8673.pdf on December 10, 2016.

Herman, S. (1998). Shake Before Using. Kosmeticos.Retrieved from http://www.stephenherman.com/002.pdf on December 20, 2016.

IARC (2004). Betel-quid and Areca-nut Chewing and Some Areca-nut-derived Nitrosamines.Monographs on the Evaluation of Carcinogenic Risks to Humans. Retrieved from https://www.ncbi.nlm.nih.gov/books/NBK316567/pdf/Bookshelf_NBK316567.pdf on December 20, 2016.

Ikpeme, C., et al. Comparative Evaluation of the Nutritional, Phytochemical and Microbial Quality of Three Pepper Varieties. Journal of Food and Nutrition Sciences.Retrieved from http://article.sciencepublishinggroup.com/pdf/10.11648.j.jfns.20140203.15.pdf $\quad$ on December 7, 2016.

Imeri, A., et al. (2014). Essential Oil Composition in Three Cultivars of Ocimum in Albania.Arch. Biol. Sci. Retrieved from http://www.doiserbia.nb.rs/img/doi/03544664/2014/0354-46641404641I.pdf on December 15, 2016. 
Imokawa, G. (1995). Structures and Functions of Stratum Corneum Lipids in the Skin.Journal of Japan Oil Chemistry Society.Vol 44 no. 10.

Jantan, I., et al. (1996). Chemical Composition of Some Citrus Oils from Malaysia.Journal of Essential Oil Research.Retrieved from http://dx.doi.org/10.1080/10412905.1996.9701030 on December 20, 2016.

Jones, O. and Selinger, B. (2016). The Chemistry of Cosmetics.Retrieved from http://www.nova.org.au/people-medicine/chemistry-cosmetics on December 20, 2016.

Karou, D., et al. (2005). Antibacterial Activity of Alkaloids from Sidaacuta.African Journal of Biotechnology. Retrieved from http://search.proquest.com/central/docview/1657301297/fulltextPDF/774B3CAB392F472 BPQ/7?accountid=141440 on December 8, 2016.

Kaul, VK., et al. (1995). Volatiles of the Absolute of Cestrum nocturnum.Journal of Essential Oil Research.Retrieved from https://eurekamag.com/pdf.php?pdf=002730870 on December 15, 2016.

Khazaeli, P. and Mehrabani, M. (2008). Screening of Sun Protective Activity of the Ethyl Acetate Extracts of Some Medicinal Plants.Iranian Journal of Pharmaceutical Research. Retrieved from http://ijpr.sbmu.ac.ir/article_738_71b3fb4f53cb8afad2d05a01c621f841.pdf on December $10,2016$.

Koba, K., et al. (2009). Chemical Composition and Cytotoxic Activity of Chenopodiumambrosioides Essential Oil from Togo.Bangladesh Journal of Scientific and Industrial Research. Retrieved from http://www.banglajol.info/bd/index.php/BJSIR/article/view/4594/3704 on December 16, 2016.

Koeler, P. and Wieser, H. (2013). Chemistry of Cereal Grains.Handbook on Sourdough Biotechnology.Retrieved from http://www.springer.com/978-1-4614-5424-3 on December $18,2016$.

Kumar, B., et al. (2016). Phytochemical and In-vitro Pharmacological Evaluation of Ipomoea sepiaria Against Selected Pathogenic Microorganisms.European Journal of Pharmaceutical and Medical Research.Retrieved from http://www.ejpmr.com/admin/assets/article_issue/1454131020.pdf on December 9, 2016.

Kumar, K., et al. (2013). A Review on Phytochemical Constituents and Biological Assay of Averrhoabilimbi.International Journal of Pharmacy and Pharmaceutical Science Research. Retrieved from http://s3.amazonaws.com/academia.edu.documents/32404717/KSK-

A.bilimbi.pdf?AWSAccessKeyId=AKIAJ56TQJRTWSMTNPEA\&Expires=1481643596 $\&$ Signature $=90 \mathrm{qH} 1 \mathrm{u} 9913 \mathrm{i} 93 \mathrm{Ci} \% 2 \mathrm{FCUFa} \% 2 \mathrm{~B} 5 \mathrm{Zq0u0 \% 3D \& response-content-}$ disposition=inline\%3B\%20filename\%3DA_REVIEW_ON_PHYTOCHEMICAL_CONS TITUENTS_A.pdf on December 10, 2016.

Lati, E. (1995). New Research and development in Moisture retention Mechanism and Moisturizing Agents.Fragrance Journal.Vol. 23 no. 81.

Logeswari, P., et al. (2013). In-vivo Anti-inflammatory effect of Aqueous and Ethanolic Extract of Sidarhombifolia Root.IJPSR.Retrieved from http://search.proquest.com/central/docview/1366362189/fulltextPDF/FF921A8B5BC64F0 5PQ/1? accountid=141440 on December 19, 2016.

Lourith, N., et al. (2013). Aroma Profiles and Preferences of Jasminumsambac Flowers Grown in Thailand.Journal of Cosmetics Science.Retrieved from http://journal.scconline.org/pdf/cc2013/cc064n06/p00483-p00494.pdf on December 15, 2016. 
Lu, R., et al. (2000). Blooming Type Disinfecting Cleaning Compositions.United States Patent.Retrieved from https://www.google.com/patents/US6066606 on December 10, 2016.

Mabeku, L., et al. (2011). Screening of Some Plants Used in Cameroonian Folk Medicine for the Treatment of Infectious Diseases.International Journal of Biology.Retrieved from http://www.ccsenet.org/journal/index.php/ijb/article/viewFile/10453/8690 on December $19,2016$.

Mangasakan, M. (2007).The Status of Teaching High School Chemistry in Cotabato City Division.Unpublished Thesis.Notre Dame University, Cotabato City.

Marshall, E., et al. (2015). Antimicrobial Screening and Phytochemical Analysis of Carica papaya Leaf Extracts. Standard Research Journal of Microbiological Sciences.Retrieved from http://standardresearchjournals.org/journals/SRJMS/pdf/2015/march/Marshall\%20et\%20al .pdf on December 8, 2016.

Maregesi, S., et al. (2014). Documentation and Phytochemical Screening of Traditional Beauty Products Used in Missenyi District of Tanzania. Journal of Cosmetics, Dermatological Sciences and Applications.Retrieved from http://file.scirp.org/Html/91050270_52246.htm on December 8, 2016.

Moghadamtousi, S., et al. (2015). Annona muricata (Annonaceae): A Review of Its Traditional Uses, Isolated Acetogenins and Biological Activities. International Journal of Molecular Sciences.Retrieved from http://www.mdpi.com/1422-0067/16/7/15625 on December 20, 2016.

Moghimipour, E. and Handali, S. Saponin: Properties, Methods of Evaluation and Applications. Annual Research and Review in Biology. Retrieved from http://search.proquest.com/openview/a27b838df6820166561b9362ac0f6590/1?pqorigsite $=$ gscholar on December 5, 2016.

Mohammed, A., et. al. (2013). Minerals Content, Essential Oils Composition and Physicochemical Properties of Citrus jambhiri from the Sudan.International Letters of Chemistry, Physics and Astronomy.Retrieved from http://search.proquest.com/openview/1f54c5238ce820d5b7b06c24f47d673e/1?pqorigsite $=$ gscholar on December 9, 2016.

Monzon, R., et al. Larvicidal Potential of Five Philippine Plants against Aedesaegypti and Culexquinquefasciatus. Sotheast Asian Journal Trop Med Public Health.Retrieved from http://www.tm.mahidol.ac.th/seameo/1994-25-4/1994-25-4-755.pdf on December 20, 2016.

Mordue, A. and Nisbet, A. (2000). Azadirachtin from the Neem Tree Azadirachtaindica: its Action Against Insects. An. Soc. Entomol. Brasil.Retrieved from http://www.scielo.br/pdf/aseb/v29n4/v29n4a01.pdf on December 20, 2016.

Motta, S., et al. (1993) Ceramide Composition of the Psoratic Scale. BichemicaetBiophysicaActa.

Mungole, A., et al. (2010). Preliminary Phytochemical Screening of Ipomoea obscura- A Hepatoprotective Medicinal Plant.International Journal of PharmTech Research.Retrieved from

http://sphinxsai.com/Oct_dec_2010_vol2_no.4/PharmTech_vol2_no.4_1_pdf/PT=28\%20( 2307-2312).pdf on December 9, 2016.

Musa, A. and Gasmelseed, G. (2012). Characterization of Lawsoniainermis as Vegetable Tanning Material.Journal of Forest Products and Industries.Retrieved from http://researchpub.org/journal/jfpi/number/vol1-no2/vol1-no2-5.pdf on December 20, 2016. 
Narendhirakannan, R. and Limmy, T. (2010). Invitro Antioxidant Studies on Ethanolic Extracts of Leaf, Stem, and Roots of Sidarhombifolia. International Journal of Pharma and Bio Sciences.Retrieved from http://www.ijpbs.net/issue-2/192.pdf on December 19, 2016.

Nascimento, G., et al. (2000). Antibacterial Activity of Plant Extracts and Phytochemicals on Antibiotic-Resistant Bacteria.Brazilian Journal of Microbiology.Retrieved from http://www.scielo.br/pdf/bjm/v31n4/a03v31n4.pdf on December 20, 2016.

Nishizawa, et. al. (1983). Structure of Lansiosides: Biologically Active New Triterpene Glycosides from LansiumDomesticum. Journal of Organic Chemistry.

NSO(2008).Retrievedfromhttps://psa.gov.ph/sites/default/files/attachments/aodao/article/T able $\% 202 . \% 20$ Basic $\% 20$ Literacy $\% 20$ Rate $\% 20$ of $\% 20$ Population $\% 2010 \% 20$ Years $\% 20$ Old $\% 20$ and $\% 20$ Over $\% 20$ and $\% 20$ Population $\% 2015 \% 20$ to $\% 2024 \% 20$ Years $\% 20$ Old $\% 2$ C $\% 20$ by\%20Sex\%2C\%20and\%20Region\%2C\%20Philippines\%202008_0.pdf

Obidoa, O., et al. (2010).Phytochemical Analysis of Cocos nucifera.Journal of Pharmacy Research.

Odenigbo, U. and Otisi, C. (2011). Fatty Acids and Phytochemical Contents of Different coconut Seed Flesh in Nigeria. International Journal of Plant Physiology and Biochemistry.Retrieved from http://www.academicjournals.org/article/article1380037061_Odenigbo\%2520and\%2520\% 2520Otisi.pdf on December 8, 2016.

Oliveira, J., et al. (2009). Phytochemical Screening and Anticonvulsant Property of Ocimumbasilicum Leaf Essential Oil. Boletin Latinoamericano y del Caribe de PlantasMedicinales y Aromaticas.Retrieved from http://www.redalyc.org/pdf/856/85611774006.pdf on December 15, 2016.

Onwuegbuzie, et. al. (2012).The Qualitative Report.Retrieved from http://www.nova.edu/ssss/QR/QR17/onwuegbuzie.pdf on July 17, 2014.

Othman, S., et al. (2016).Essential Oils from the Malaysian Citrus Medicinal Plants.Journal of Medicines.Retrieved from http://www.mdpi.com/2305-6320/3/2/13/htm December 20, 2016.

Oyi, A., et al. Formulation and Antimicrobial Studies of Coconut Oil. Research Journal of Applied Sciences, Engineering and Technology.Retrieved from http://lovewildorganics.co.uk/wp-content/uploads/2014/12/Coconut-Oil.pdf on December 6, 2016.

Padmalochana, K. and Rajan, M. (2014). Antimicrobial Activity of Aqueous, Ethanol and Acetone Extracts of Sesbania grandiflora Leaves and its Phytochemical Characterization. International Journal of Pharma Sciences and Research.Retrieved from http://www.ijpsr.info/docs/IJPSR14-05-12-035.pdf on December 4, 2016.

Paridhi, B., et al. (2015). An Invitro Study of Determination of Anti-bacterial, Antioxidant, Anti-inflammatory Potential of Piper betel Essential Oil.Retrieved from http://www.ijrap.net/admin/php/uploads/1525_pdf.on December 20, 2016.

Patil, P., et al. (2009). Pharmacological Activities of Areca catechu- A Review.Journal of Pharmacy Research.Retrieved from http://jprsolutions.info/files/final-file56948d3c4ccdb9.87549482.pdf on December 20, 2016.

Peters, D. (1994). Terpene Cleaning Compositions and Methods of Using the Same.United States Patent.Retrieved from https://www.google.com/patents/US5277836 on December 10, 2016.

Punjee, P., et al. (2009). Scented Extracts and Essential Oil Extraction from Micheliaalba. Journal of Natural Science.Retrieved from 
Ethnochemistry of maguindanaons on the usage of household chemicals ...

http://www.thaiscience.info/Article\%20for\%20ThaiScience/Article/62/10034075.pdf on December 15, 2016.

Quisumbing, E. (1978). Medicinal Plants of the Philippines.Katha Publishing House. Quezon Avenue, Quezon City.

Raj, G., et al. (2010). Coconut Oil: Chemistry, Production and its Applications- A Review. Indian Coconut Journal.Retrieved from http://www.coconutboard.in/docs/English-Article-Gopalakrishna-CFTRI.pdf on December 8, 2016.

Rao, V, et al. (2009). Comparison of Essential Oil Components in Rhizome and Invitro Regenerated Whole Plants of Kaempferia galangal.Journal of Medicinal and Aromatic Plant Sciences. Retrieved from http://www.researchgate.net/publication/256385545 on December 18, 2016.

Rawat, A. and Mali, R. (2013). Phytochemical Properties and Pharmacological Activities of Nicotianatabacum: A Review. Indian Journal of Pharmaceutical and Biological Research.Retrieved from http://ijpbr.in/wp-content/uploads/2013/10/12-RR-mali.pdf on December 20, 2016.

Roy, A. and Saraf, S. (2005). Limonoids: Overview of Significant Bioactive Triterpenes Distributed in Plants Kingdom. Boil. Pharm. Bull. Retrieved from https://www.jstage.jst.go.jp/article/bpb/29/2/29_2_191/_pdf on December 20, 2016.

Sabharwal, S., et al. (2013). Jasminumsambac: A Review. International Journal of Pharmaceutical Research and Bio-Science.Retrieved from http://www.ijprbs.com/issuedocs/2013/10/IJPRBS\%20430.pdf on December 15, 2016.

Sahayaraj, K. and Ravi, C. (2008). Preliminary Phytochemistry of Ipomoea carnea and Vitexnegundo Leaves. International Journal of Chemical Science.Retrieved from http://www.sadgurupublications.com/ContentPaper/2008/1_6(1)2008.pdf on December 8, 2016.

Sainath, M., et al. (2016). Formulation and Evaluation of Herbal Lipstick.International Journal of Advanced Research in Medical and Pharmaceutical Sciences.Retrieved from http://www.ijarmps.org/wp-content/uploads/2016/02/4.Formulation-And-Evaluation-ofHerbal-Lipstic.pdf on December 15, 2016.

Sani, I., et. al. (2014). Evaluation of Physicochemical Properties, Phytochemicals and Mineral Composition of Cocos nucifera Kernel Oil.International Journal of Advanced Research in Chemical Science.Retrieved from https://www.arcjournals.org/pdfs/ijarcs/v1i8/4.pdf on December 8, 2016.

Saraswati, J., et al. (2016). Analytical Techniques for Phytochemicals Screening and Bioactivities of Some Coleus Species: A Review. Journal of Pharmaceutical Science and Research.Retrieved from http://www.jpsr.pharmainfo.in/Documents/Volumes/vol8Issue04/jpsr08041611.pdf on December 15, 2016.

Sazwi, N., et al. (2013). Antioxidant and Cytoprotective Activities of Piper betle, Areca catechu, Uncariagambir and Betel quid with and without Calcium Hydroxide.BMC Complementary and Alternative Medicine. Retrieved from http://download.springer.com/static/pdf/550/art\%253A10.1186\%252F1472-6882-13-

351.pdf?originUrl=http $\% 3 \mathrm{~A} \% 2 \mathrm{~F} \% 2 \mathrm{Fbmccomplementalternmed.biomedcentral.com} \% 2 \mathrm{Fa}$ rticle\%2F10.1186\%2F1472-6882-13

351\&token $2=\exp =1481756567 \sim$ acl $=\% 2$ Fstatic $\% 2$ Fpdf $\% 2$ F $550 \% 2$ Fart $\% 25253 \mathrm{~A} 10.1186$ \%25252F1472-6882-13-

351.pdf* hmac $=9 \mathrm{c} 965369 \mathrm{bcd} 77 \mathrm{c} 9 \mathrm{e} 4605 \mathrm{e} 7 \mathrm{~b} 4 \mathrm{~d} 8 \mathrm{e} 4106 \mathrm{f} 770792 \mathrm{e} 08058973 \mathrm{f} 02 \mathrm{f} 8 \mathrm{e} 7 \mathrm{fee} 35 \mathrm{c} 4$ d2d on December 20, 2016. 
SEAMEO INNOTECH (2007). Retrieved from http://www.seameo-innotech.org/wpcontent/uploads/2014/01/Policy-Research-on-Access-to-Quality-Basic-Education-forMuslim-Learners.pdf on February 10, 2016.

Sherwani, S., et al. (2013). Qualitative Phytochemical Screening and Antifungal Activity of Carica papaya Leaf Extract against Human and Plant Pathogenic Fungi.International Research Journal of Pharmacy.Retrieved from http://www.irjponline.com/admin/php/uploads/1897_pdf.pdf on December 7, 2016.

Shizha, E. (2005). Indigenous Knowledge and Languages in the Teaching and Learning of Science: A Focus on a Rural Primary School in Zimbabwe. Retrieved from http://adsabs.harvard.edu on December 6, 2014.

Singh, I. and Chibuye, B. (2016). Effect of Ethnochemistry Practices on Secondary School Students' Attitude Towards Chemistry. Journal of Education and Practice.Retrieved from http://www.iiste.org on December 26, 2016.

Solidum, J. (2012). Potential Nutritional and Medicinal Sources from Fruit Peels in Manila, Philippines. International Journal of Bioscience, Biochemistry and Bioinformatics.Retrieved from http://www.ijbbb.org/papers/114-A00017.pdf on December 20, 2016.

Soumya, S. and Nair, B. (2012). Antifungal Efficacy of Capsicum frutescens Extracts Against Some Prevalent Fungal Strains Associated with Groundnut Storage. Journal of Agricultural Technology.Retrieved from http://www.ijataatsea.com/pdf/v8_n2_12_March/29_IJAT\%202012_8_2_S.L.pdf on December 5, 2016. Suresh, K., et al. (2008). Antimicrobial and Phytochemical Investigation of the Leaves of Carica papaya, Cynodondactylon, Euphorbia hirta, Melia azedarach, and Psidiumguajava.Ethnobotanical Leaflets.Retrieved from https://pdfs.semanticscholar.org/d3b8/1025ca493972d0cccf370f5ca4f5187c5c45.pdf on December 8, 2016.

Talib, W. (2010). Anticancer and Antimicrobial of Plant-Derived Natural Products.Phytochemicals-Bioactivities and Impact on Health.Retrieved from http://cdn.intechopen.com/pdfs/25497.pdf on December 16, 2016.

Tan, L., et al. (2015). Traditional Uses, Phytochemistry, and Bioactivities of Canangaodorata. Hindawi Publishing Corporation Evidence-Based Complementary and Alternative $\quad$ Medicine. Retrieved from https://www.ncbi.nlm.nih.gov/pmc/articles/PMC4534619/pdf/ECAM2015-896314.pdf on December 16, 2016.

Tewtrakul, S., et al. (2005). Chemical Components and Biological Activities of Volatile Oil of Kaempferia galangal.Songklanakarin Journal of Science and Technology.Retrieved from http://www.researchgate.net/publication/26470656 on December 8, 2016.

ul-Haq, A. and ur-Rehman, S. (2004). Chicken Eggs A Diverse Food. World Food Day Proceedings.Retrieved from http://www.researchgate.net/publication/297714605 on December 19, 2016.

Umadevi, M., et al. (2012). Rice-Traditional Medicinal Plant in India.Journal of Pharmacognosy and Phytochemistry.Retrieved from http://www.phytojournal.com/vol1Issue1/Issue_may_2012/1.2.pdf on December 19, 2016. USAID (2007). Policy Research on Access to Quality Basic Education For Muslim Learners.Retrievedfromhttp://www.iyfnet.org/sites/default/files/Quality_BasicEd_4_Musli ms.pdf on Novermber 10, 2015.

Vesper, H. et al. (1999) Sphingolipids in Food and the Emerging Importance of Sphingolipids to Nutrition.Journal of Nutrition.Vol 129. Pp 1239-1250. 
Vijayameena, C., et al. (2013). Phytochemical Screening and Assessment of Antibacterial Activity for the Bioactive Compounds in Annona muricata. International Journal of Current Microbiology and Applied Sciences. Retrieved from https://www.researchgate.net/profile/Balasubramanian_Ramesh/publication/234076924_P hytochemical_screening_and_assessment_of_antibacterial_activity_for_the_bioactive_co mpounds_in_Annona_muricata/links/09e4150ede8ee1e2a4000000.pdf on December 20, 2016.

Woldeyes, S., et al. (2012). Evaluation of Antibacterial Activities of Compounds Isolated from Sidarhombifolia.Natural Products Chemistry and Research.Retrieved from http://www.esciencecentral.org/journals/evaluation-of-antibacterial-activities-of-

compounds-isolated-from-sida-rhombifolia-linn-malvaceae-2329-

6836.1000101.php?aid=11304 on December 18, 2016.

Yanagida, T. (2003). Properties of Wax Extracted from Banana Leaves. ASABE Journal. Retrieved

from https://elibrary.asabe.org/abstract.asp?aid $=14121 \& \mathrm{t}=2 \&$ redir=\&redirType $=$ on December 7, 2016.

Yuswantina, R., et al. The Effectiveness of the Formulation of Hand Antiseptic Gel of Extract of Turi (Sesbania grandiflora) Leaves. Retrieved from http://perpusnwu.web.id/karyailmiah/documents/3917.pdf on December 5, 2016.

\section{Biography}

Norolayn K. Said-Ador is a faculty member of Mindanao State University-Institute of Science Education (MSU-ISED), Marawi City. She is currently working on her Ph.D. (in Science Education major in Chemistry) dissertation (taken at MSU-IIT, Iligan) entitled, Ethnochemistry of Maguindanaons: Basis for Information and Communication Technology (ICT)-Based Lessons under the advisory of Dr. Thelma A. Antonio and Dr. Myrna E. Lahoylahoy. The study presented above is a portion of the first phase of her dissertation. And she is a recipient of Department of Science and Technology (DOST) scholarship. 